\title{
ZLATA PLAKETA UNIVERZE V LJUBLJANI PROF. DR. KLAUSU WOLFU
}

Na svečanem zasedanju Senata Univerze v Ljubljani 3. decembra 2003 je Univerza Ljubljani mednarodno priznanemu profesorju geografije na Univerzi v Frankfurtu/Main prof. dr. Klausu Wolfu podelila zlato plaketo za njegovo dolgoletno sodelovanje z Oddelkom za geografijo Filozofske fakultete in s slovensko geografijo na sploh. Ker se prof. Wolf podelitve na Univerzi ni mogel udeležiti, mu je bila plaketa predana ob krajši slovesnosti na Oddelku za geografijo Filozofske fakultete 1. oktobra 2004.

Poglobljeno sodelovanje Oddelka za geografijo Filozofske fakultete v Ljubljani in Instituta für Kulturgeographie, Stadt und Regionalforschung sega v leto 1969, ko se je prof. Wolf v Ljubljani udeležil jugoslovanskega simpozija o urbani geografiji in se je po letu 1972, ko je postal redni profesor in direktor Inštituta, kar je ostal vse do odhoda v pokoj 31. marca 2004, še okrepilo in močno razvejalo tako na institucionalni kot na osebni ravni. Skorajda ni starejšega slovenskega visokošolskega učitelja, ki ne bi obiskal Kulturnogeografskega inštituta v Frankfurtu, v sodelovanje pa so bili vključeni še sodelavci Pedagoške akademije, kasneje Fakultete v Mariboru in Geografskega inštituta iz Ljubljane. Če prištejemo še številne naše ekskurzije, ki so jih po Frankfurtu in njegovem obmestju vodili prof. Wolf in njegovi sodelavci lahko z gotovostjo trdimo, da se s tolikšnim številom slovenskih geografov kot prof. Wolf ni srečal nobeden tuji geograf. Kar nekaj slovenskih "družbenih" geografov se je daljši ali krajši čas strokovno izpopolnjevalo v Frankfurtu zahvaljujoč finančni podpori DAAD, ki je podprla tudi nekaj naših terenskih vaj v ZRN in drugih oblik sodelovanja.

Prof. Wolf se je prvenstveno ukvarjal s proučevanjem mest in drugih naselij, z regionalnim planiranjem, s proučevanjem terciarnih dejavnosti od turizma do oskrbe in druge infrastrukture, pa tudi z regionalno razvojno problematiko Nemčije in njenih regij, še posebej z zgostitveno Regijo Ren-Maina. O tem je in številnih medoddelčnih seminarjih v Ljubljani in v Frankfurtu seznanjal tudi številne slovenske geografe. Ker so bili prispevki vsakokratnih seminarjev, h katerim smo pritegnili tudi kolege izven Oddelka, tiskani v Rhen Mainische Forschungen, v Materialien, v Arbeitsmaterialien zur Raumordnung und Raumplanung iz Bayreutha, v Geographici Slovenici in v oddelčni znanstveni reviji DELA, je bil to velik prispevek k uveljavljanju slovenske geografije v mednarodni strokovni javnosti. Ni treba posebej poudarjati znanstvenost, sistematičnost, nazornost in aplikativno naravnost prof. Wolfovih del, kar na slovenske kolege ni imelo majhnega vpliva. Tisti, ki smo več časa prebili na Inštitutu v Frankfurtu, smo lahko neposredno spremljali Wolfovo odlično pedagoško delo, njegovo vodenje izdelave doktorskih nalog in drugih projektov, ki so se praviloma lotevali najbolj aktualnih regionalno razvojnih problemov s ciljem prispevati čim več k njihovemu poznavanju, razumevanju in reševanju. Zato ni slučaj, da so številni njegovi doktoranti dobili vidne in tudi najvidnejše položaje v regionalnem in urbanem planiranju.

Prof. Wolf je vedno iskal odgovore na hitro se spreminjajočo regionalno razvojno problematko, ki je bila še posebej dinamična v območju njegovega težiščnega delovanja, to je v Frankfurtski zgostitveni aglomeraciji. To je razen z znanstveno raziskovalnim delom opravljal od prvega dne svoje profesure in direktorovanja tudi s publicističnim in organiza- 
cijskim delovanjem. Kar dvaintrideset let je bil od leta 1972 izdajatelj in glavni urednik v Nemčiji zelo cenjene znanstvene revije Rhen Mainische Forschungen, v obdobju 1876 1991 pa je predsedoval Frankfurtskemu geografskemu društvu. Leta 1979 je ustanovil in do leta 2003 predsedoval Gesellschaft für regionalwissenschaftliche Forschung (za Regijo Rhen Main). V letih 1982 - 97 je bil glavni urednik Berichte zur deutschen Landeskunde" nemške Akademie für Landeskunde. Od leta 1984 je bil dopisni in od leta 1990 redni član Akademie für Raumforschung und Landesplanung iz Hannovra, v kateri je bil v letih 1993 - 1995 član predsedstva, od 1995 - 1996 in 1999 - 2000 podpredsednik, v letih 1997 1998 pa celo njen predsednik. Še bi lahko naštevali vrsto vodstvenih funkcij prof. Wolfa v raznih strokovnih z regionalim planiranjem povezanih društvih, ustanovah, pa na Univerzi in na drugih nemških univerzah. $Z$ vsem tem obsežnim delom je prof. Wolf veliko prispeval tako $\mathrm{k}$ razvoju posameznih geografskih področij in $\mathrm{k}$ njeni uveljavitvi v praksi in $\mathrm{v}$ družbi.

Njegovi prijatelji in kolegi si štejemo v čast, da imamo že desetletja srečo sodelovati s prof. Wolfom. Za slovenske geografe in geografijo je vedno kazal veliko zanimanje in zato je Slovenijo zelo rad obiskoval, jo dodobra spoznal in na marsikaj zanimivega tudi opozarjal. Oddelek za geografijo Filozofske fakultete je s Kulturnogeografskim inštitutom iz Frankfurta že v osemdesetih letih prejšnjega stoletja sklenil uradno pogodbo o sodelovanju, ki se bo, upamo, tudi po njegovi upokojitvi nadaljevalo.Zlata plaketa Univerze v Ljubljani, pa sprejema udeležencev zadnjih dveh medinštitutskih seminarjev 2002 leta pri županji Ljubljane in županu Frankfurta so le skromno priznanje za dolgoletno sodelovanje in veliko korist, ki jo je od tega imela slovenska geografija. Ob tem si želimo tudi v bodoče čim več srečanj s prof. Klausom Wolfom.

Mirko Pak 